\title{
Evaluating the impact of high protein snack foods compared with standard protein snack foods on energy intake and appetite ratings for social drinkers: a pilot study
}

\author{
A. Kwok, A. Dordevic and H. Truby \\ Department of Nutrition, Dietetics and Food, Faculty of Medicine, Nursing and Health Sciences, Monash University, \\ Victoria, Australia
}

Consumption of alcoholic beverages may stimulate food energy intake and contribute to passive overconsumption ${ }^{(1)}$. As protein is the most satiating of all the macronutrients, substituting protein for fat or carbohydrate in the diet may promote satiety and minimise excess consumption ${ }^{(2,3)}$. The aim of this study was to assess the difference in food energy intake between consuming high protein snack foods compared with standard protein snack foods, after ingestion of a moderate dose of alcohol.

A randomised single-blind crossover trial, involving nineteen participants aged 19-31 years, was conducted. Participants attended two separate study visits one week apart, where they ingested white wine ( $30.0 \mathrm{~g}$ of alcohol) and offered ad-libitum access to either high protein savoury snacks $(15.9 \mathrm{~g}$ protein $/ 100 \mathrm{~g})$ with a protein-fortified dip or standard protein savoury snacks $(4.4 \mathrm{~g}$ protein $/ 100 \mathrm{~g})$ with dip which were matched for fat and carbohydrate content. Food energy intake was measured by weighing pre- and post-snacks and calculating energy consumed. Visual analogue scales were completed at $0,15,30,45,60,90,120$ and 180 minutes after consumption of the wine to measure subjective feelings of hunger, fullness and desire to eat.

There were no significant differences in mean food energy intake between the high-protein snacks and standard protein snacks $(\mathrm{P}=0 \cdot 28)$. Mean protein intake was significantly higher in the high protein snack group than in the standard protein snack group $(\mathrm{P}<0.001)$ whereas no significant differences were observed between the groups for mean fat intake $(\mathrm{P}=0.25)$ and mean carbohydrate intake $(\mathrm{P}=0 \cdot 38)$. There were no significant differences between the groups for total area under the curve (tAUC) for median hunger, median fullness and mean desire to eat (all $\mathrm{P}>0 \cdot 05$ ).

\begin{tabular}{|c|c|c|c|c|}
\hline & \multicolumn{2}{|c|}{$\begin{array}{c}\text { High } \\
\text { protein snacks } \\
(\mathrm{n}=19)\end{array}$} & \multicolumn{2}{|c|}{$\begin{array}{c}\text { Standard } \\
\text { protein snacks } \\
(\mathrm{n}=19)\end{array}$} \\
\hline & Mean & SD & Mean & SD \\
\hline Food energy intake (kilojoules) & 4664 & 1402 & 4343 & 1297 \\
\hline Protein intake (grams) & $46 \cdot 4^{\mathrm{a}}$ & $13 \cdot 8$ & $12 \cdot 9^{\mathrm{a}}$ & $4 \cdot 8$ \\
\hline Fat intake (grams) & $55 \cdot 6$ & $18 \cdot 5$ & $59 \cdot 3$ & $20 \cdot 0$ \\
\hline Carbohydrate intake (grams) & $105 \cdot 0$ & $33 \cdot 9$ & $111 \cdot 0$ & $33 \cdot 8$ \\
\hline Hunger tAUC (mm*180 mins) & $6060^{\mathrm{b}}$ & $3748^{\mathrm{c}}$ & $6428^{b}$ & $3666^{\mathrm{c}}$ \\
\hline Fullness tAUC (mm*180 mins) & $9154^{\mathrm{b}}$ & $4774^{\mathrm{c}}$ & $9345^{\mathrm{b}}$ & $4089^{c}$ \\
\hline Desire to eat tAUC (mm*180 mins) & 7838 & 1161 & 7229 & 2719 \\
\hline
\end{tabular}

In conclusion, ad libitum consumption of high protein snacks did not reduce food energy intake or induce greater satiety compared with consumption of standard protein snacks, after ingestion of a moderate dose of alcohol. This suggests that alcohol consumption may be indiscriminate in stimulating consumption of food, regardless of protein content. These initial data warrant further investigation to substantiate these findings, as well as replicating these methods with consumption of different types of alcoholic beverages.

This research was funded by a Coopers Foundation Grant and an Australian Government Research Training Program Scholarship.

1. Yeomans M (2010) Physiol Behav 100, 82-89.

2. Halton TL, Hu FB (2004) J Am Coll Nutr 23, 373-385

3. Tannous dit El Khoury D, Obeid O, Azar ST et al. (2006) Ann Nutr Metab 50, 260-269. 